\title{
A KÖZNEVELÉSBEN RÉSZTVEVÖ FOGYATÉKOS TANULÓK SPORTOLÁSI SZOKÁSAINAK VIZSGÁLATA
}

\section{STUDY OF SPRTOLING HABITS OF STUDENTS WITH DISABILITIES IN PUBLIC EDUCATION}

\author{
Laoues-Czimbalmos Nóra \\ Múvészetnevelési, Sport és Egészségnevelési Tanszék, Gyermeknevelési és Gyógypedagógiai kar \\ Debreceni Egyetem, Magyarország \\ https://doi.org/10.47833/2021.1.ART.004
}

\section{Kulcsszavak:}

Fogyatékos tanulók

Sportolási szokások

Köznevelés

\section{Keywords:}

Students with disabilities

Sports habits

Public education

\section{Cikktörténet:}

Beérkezett 2021. január 10 .

Átdolgozva 2021. március 20.

Elfogadva 2021. április 5.

\begin{abstract}
Összefoglalás
A kutatás a köznevelésben résztvevő fogyatékossággal éló tanulók sportolási szokásait elemzi ( $N=1158)$, az ÉszakMagyarországi (Borsod-Abaúj-Zemplén, Heves, Nógrád) és Észak-Alföldi (Hajdú-Bihar, Jász-Nagykun-Szolnok, SzabolcsSzatmár-Bereg) régiókban. A fogyatékossággal élő tanulók nagy része $(75,3 \%)$ szeret sportolni, képesnek érzi magát rá és igénye is van a több sportolásra, valamint fontosnak tartják azt. A fiúk sporthoz való pozitív attitúdje és a sportolási aktivitása magasabb a lányokhoz viszonyítva.
\end{abstract}

\begin{abstract}
The research analyzes the sports majors of students with disabilities participating in public education ( $N=1158)$, in Northern Hungary (Borsod-Abaúj-Zemplén, Heves, Nógrád) and in the Northern Great Plain (Hajdú-Bihar, Jász-Nagykun-Szolnok, Szabolcs-Szatmár-Bereg) regions. The majority of students with disabilities (75.3\%) like to play sports, feel able to do so and have a need for more sports, and consider it important. Boys 'positive attitudes toward sports and sports activity are higher compared to girls
\end{abstract}

\section{Bevezetés}

Napjainkban a fizikai inaktivitás növekedése világméretü probléma, így számos tanulmány foglalkozik akár az inaktivitás okaival, vagy annak nemzetgazdasági kérdéseivel akár a sportolás egészségben betöltött szerepével [1]; [2]; [3], mentális egészségre gyakorolt hatásaival [4], vagy a sportolás hiányának egészségre gyakorolt hatásaival [5], mely már a fogyatékossággal élő személyek célcsoportrjában is vizsgálatra került [6]; [7].

A háztatások és a munkafolyamatok gépesítésével a mozgáshiányos életmód terjedt el, mely szinte valamennyi korosztályt érinti [8]; [9]; [10]; [11]; [12]; [13]; [14]. A mozgáshiány kompenzálásának egyik jó eszköze, ha a rekreációs tevékenységek között a sportra szánt időt növeljük, vagyis a sportolásra fordított idő és a sportolók számának növelésével a fizikai inaktivitás részben kompenzálható lenne.

A sportolás szerepe és jelentősége az egészség megőrzésében vitathatatlan, melyet számos tanulmány megerősít [15]; [16]. Talán éppen ezért napjainkban egyre több kutatás irányul az aktív vagy a passzív [17]; [18]; [19] sportfogyasztásra, a sportmotivációra.

\footnotetext{
* Kapcsolattartó szerző. Email cím: laoues.nora@ped.unideb.hu
} 
Az aktív sportolási szokások vizsgálatával több hazai és nemzetközi kutatás is foglalkozik, amelyek a különböző életkorokban, különböző célcsoportok esetében vizsgálják, akár a keresleti akár a kínálati oldalt. Ezek a kutatások azonban leginkább az épek célcsoportjára fókuszál. Igaz, hogy 2004-ben, amikor Magyarország belépett az Európai Unióba, talán növekvő figyelem helyeződött a fogyatékossággl élő emberek jogaira, azoknak a biztosítására, így az egészséghez vagy a sporthoz való jog is fokozottabb figyelmet kapott. Mindezen törekvések ellenére igen kevés azoknak a kutatásoknak a száma, melyek a fogyatékossággal élő személyek célcsoportját vizsgálja különböző aspektusból, így például a sportfogyasztási szokásaikat, melyek segíthetik a fogyatékossggal élő személyek társadalmi integrációját [20]; [21]; [22] és egyben segíthetnek az állapotuk javításában [23]; [24]; [25]; [26] vagy akár az egészségi állapotuk megörzésében is.

\section{Szakirodalmi áttekintés}

Magyarországon a fogyatékos személyekre fókuszáló kutatások a rendszerváltás után vettek lendületet [27]; [28]; [29]; [30]; [31]; [32]. A fogyatékossággal élő személyek esetében a versenysportra sokkal nagyobb figyelmet szentelnek és több állami forrásban is részesül, mint a szabadidősport. A fogyatékossággal élő személyek szabadidős sportolásának ösztönzése kiemelt jelentőséggel bír, hiszen pozitívan hat az egészségi állapotukra és javítja az életminőségüket [33]. Ugyanakkor a hazai és nemzetközi kutatások arról számolnak be, hogy a fogyatékos populáció közül igen csekély azoknak a száma, akik rendszeresen szabadidős sporttevékenységet végeznek [34]; [35]. Hazai kutatások megerősítik azt is, hogy az akadálymentesített speciális infrsatruktúra hiánya is negatívan befolyásolja a fogyatékossággal élő személyek részvételét a szabadidős sportban, a rekreációban [36]; [37]; [38]; [39]; [40]; [41], ezért ezeknek a folyamatos fejlesztése is ösztönözheti a fogyatékossággal élő személyek részvételét a szabadidős sportban, rekreációban.

A rekreációs tevékenységek közül fontos a rendszeres sportolás, melynek jelentőségét több kutatás is megerősíti [42]; [25]; [34]; [43]; [44]; [45], mivel segítheti őket az egyéni állapotuk és életminőségük javításában, a közösségi élmények szerzésében, a társadalomba való beilleszkedésben.

Más kutatások a fogyatékossággal élő tanulók adaptált testnevelésére, annak lehetőségeire hívják fel a figyelmet, mely szintén a mozgásszükségletük kielégítését és egyéni állapotuk javítását vagy megtartását is támogathatja az oktatási és nevelési feladatokon túl [46]; [47]; [48]; [49]; [50] .

Magyarországon leginkább a fogyatékkal élő felnőtt lakosság sportolási szokásai kerültek a kutatások fókuszába [25]; [34].

Hazai reprezentatív kutatás számol be a felnőtt fogyatékossággal élők sportolási szokásairól és a sportmotivációs tényezőkről vagy a sporttól való távolmaradás legfőbb okairól. $A$ vizsgálat bizonyította, hogy a versengés, a fittségi állapotuk javítása vagy a képességek fejlesztése a társadalomba való beilleszkedés lehetősége, illetve a jó társaság vagy az új emberek megismerése motiválja a fogyatékkal élőket leginkább hogy részt vegyenek szabadidős sportban [25]. A magas költségek és az időhiány voltak azok az okok, melyek a sporttól való távolmaradást eredményezték.

Gombás (2017) látássérült felnőtteket vizsgált Budapesten ( $N=140)$, megállapította, hogy akik gyermekkorukban sportoltak, azok voltak azok, akik felnőtt korukban is tovább vitték a sportolási szokásaikat, mely kutatás felhívja arra a figyelmet, hogy a fogyatékkal élő gyerekek sportolását kell ösztönözni, hogy beépülve az életmód elemmé válva felnőttként is tovább folytathassák azt.

Hazai nagymintán még eddig nem készült olyan kutatás, mely a fogyatékossággal élő gyerekek sportolási és szabadidőeltöltési szokásait vizsgálja. Korábbi kutatásaink [39]; [43], melyek pilot kutatások eredményeit ismertette is alacsonyabb elemszámú vizsgálati mintán készült. Így jelen kutatás, mely több, mint 1000 fő fogyatékossággal élő gyerek eredményeit ismerteti hiánypótló ezen a területen.

\section{Anyag és módszer}

Ezt a kutatást Észak- Magyarország (23,9\%) Borsod-Abaúj-Zemplén, Heves, Nógrád és Észak-Alföld $(76,1 \%)$ Hajdú-Bihar, Jász-Nagykun-Szolnok, Szabolcs-Szatmár-Bereg régióiban a köznevelésben résztvevő fogyatékos tanulók (8-18 évesek) körében végeztem el (1. bra). 


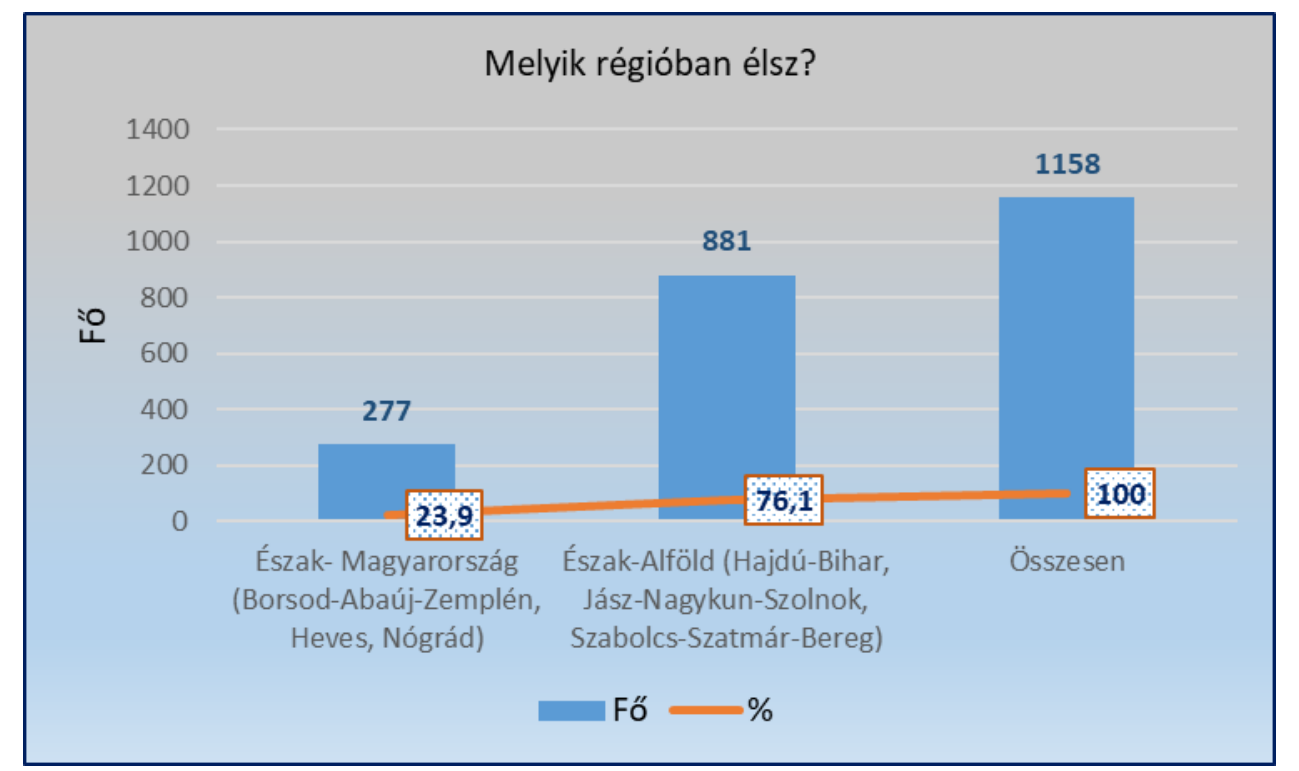

1. ábra: A válaszadók lakóhelye régió szerinti megoszlásban (Forrás: a Szerző)

A kutatási kérdések megválaszolásához a primer kutatási módszerek közül az egyszeri keresztmetszeti kutatást választottuk. A tanulók szegregált és integrált többségi iskolákból kerültek ki, a kérdőív kitöltetésében a FODISZ (Fogyatékosok Országos Diáksport,-versenysport és Szabadidősport Szövetsége) segített a fogyatékossággal élő tanulók elérésében ( $n=1158)$. Az 1436 kérdőívből 1158 volt értékelhető, így a válaszadási arány $80 \%$-os volt.

Az adatgyűjtést 2018/2019 és a 2019/2020.tanévekben végeztem, önkitöltéses kérdőíves módszert alkalmaztam, melynek legfontosabb célja a fogyatékos diákok sportolási szokásának elemzése volt.

A kérdőív itemei a szociodemográfiai változókon túl kiterjedtek a tanulók sportolási szokásaira, továbbá a fogyatékos gyerekek sport iránti attitüdjét néztük meg, valamint a nemek vonatkozásában hasonlóságokat és különbségeket figyeltünk meg, hogy van-e eltérés a sportolási aktivitás és a sporthoz való attitüd között fogyatékossággal élö gyerekek mintájában. A kérdőív kitöltése osztályfönöki óra keretében történt, a tanulók az adatfelvétel során kérdezőbiztosok (pedagógusok) segítségével, irányításával végezték a kérdőívek kitöltését. Az adatok kinyerése után SPSS statisztikai programmal elemeztem a kapott eredményeket az alapstatisztikán túl az összefüggések vizsgálatára Khí-négyzet próbát alkalmaztunk.

Az alábbi kérdésekre kerestem a választ:

- Hogyan alakul az általam felmért két régióban a fogyatékossággal élő tanulók sportolási aktivitása?

- Milyen a sporthoz való attitüdjük?

- A nemek tekintetében figyelhető-e meg eltérés a sportolási aktivitás és a sporthoz való attitüd között?

\section{Eredmények}

A tanulók életkor és nemek szerinti megoszlása

A diákok életkori eloszlását a 2. ábrán figyelhető meg, amely azt mutatja, hogy a kutatásban a 18 évesek (fiúk, 12,5\%; lányok; 16,5\%) adták meg a legtöbb választ és a legkevesebbet a 8-9 évesek. Tehát életkorukat tekintve döntően a 13-18 év közötti korcsoportba találhatóak, ugyanakkor a 8-12 év közötti korcsoportból is került a mintába néhány tanuló. A megkérdezett tanulók $54,5 \%$-a fiú és $45,5 \%$ pedig lány. Az eredményeket a 2 . ábra szemlélteti. 


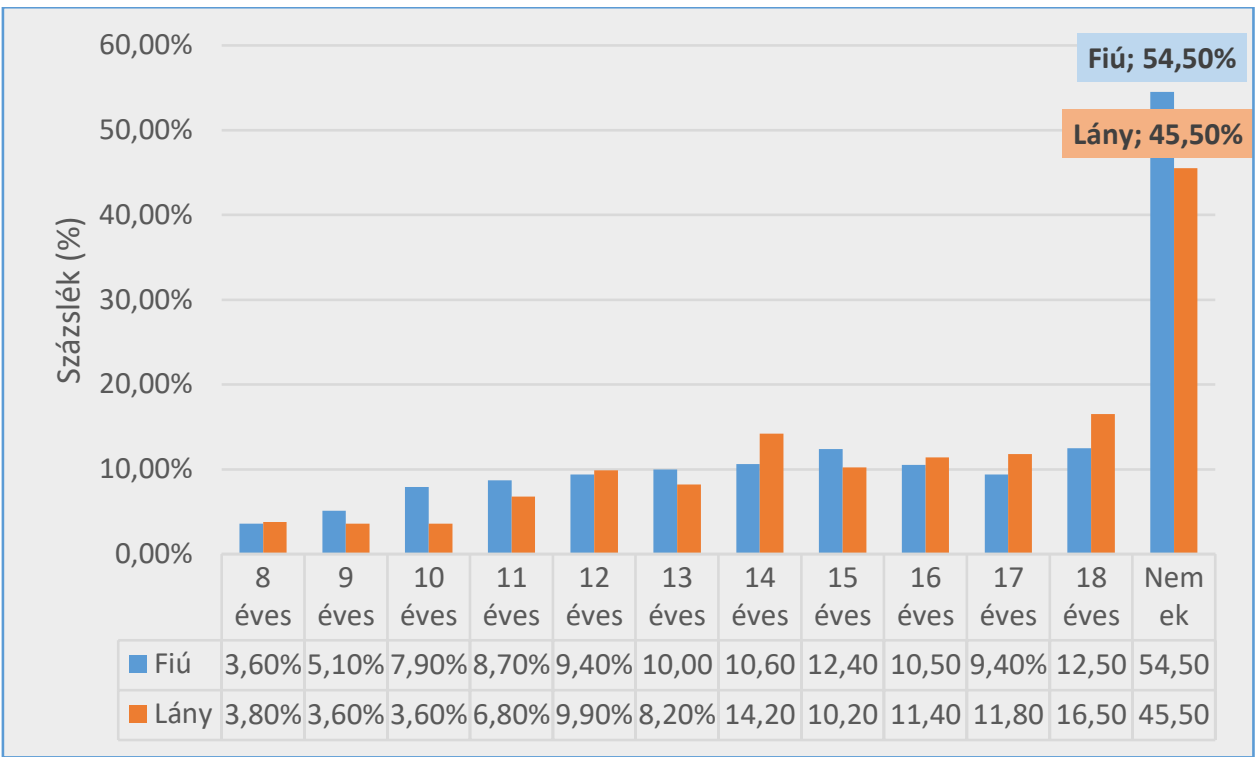

2. ábra: A felmért diákok nemek és életkor szerinti megoszlása (Forrás: a Szerző)

\section{Fogyatékossági típus}

A szociodemográfiai változók közül azt is megvizsgáltam, hogy a fiatalok milyen fogyatékossági specifikumai vannak és milyen arányban jelennek meg a válszadásban. A legtöbb válaszadó tanulásban akadályozott tanuló $(68,3 \%)$. A többi fogyatékossági ágban tartozó tanuló közel azonos arányban vettek részt a felmérésben, beszédfegyatékos tanulók aránya $8,4 \%$, a mozgáskorlátozott gyermekek aránya 7,9\%, az értelmileg akadályozott diákok aránya 6,4\%, a hallássérült tanulók aránya $6,3 \%$. A kutatásban a látássérült $(2,7 \%)$ tanulók adták a legkevesebb választ.

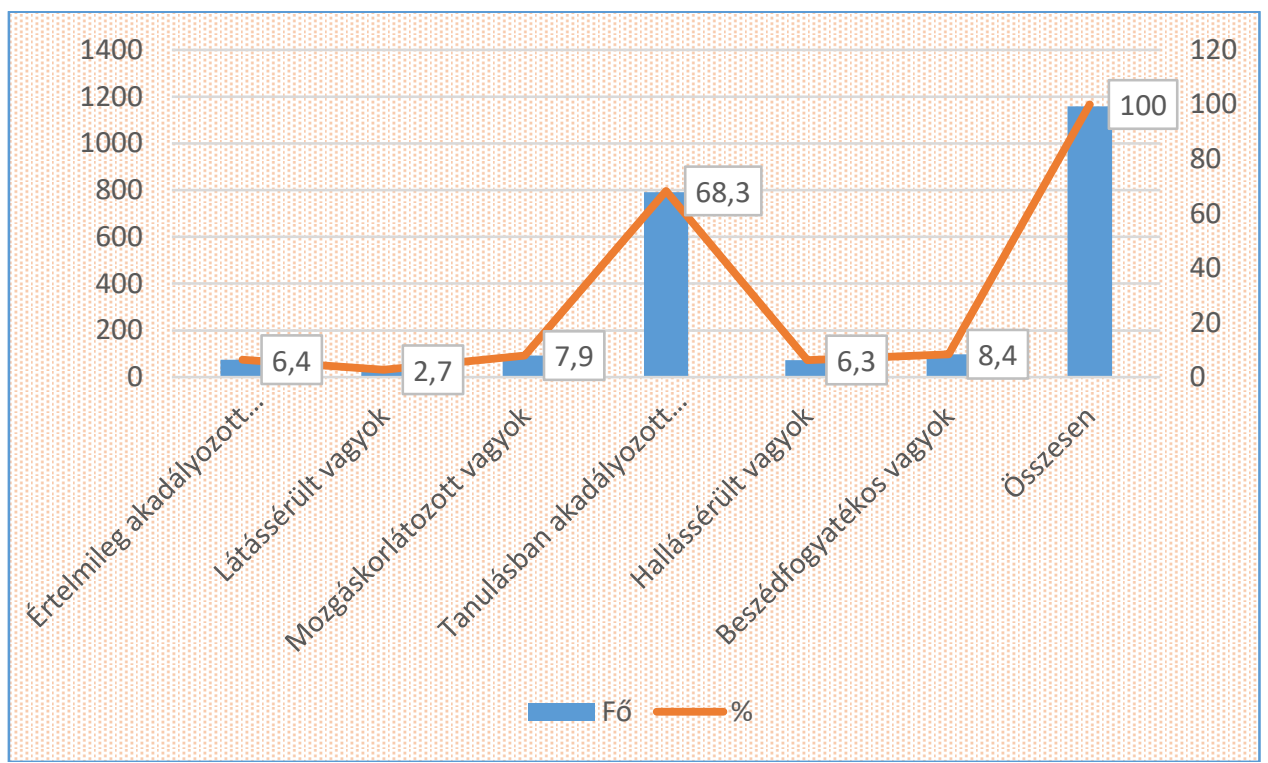

3. ábra: A felmért diákok fogyatékos-specifikus megoszlása (Forrás: a Szerző)

\section{A tanulók sportolási attitüdjük}

A sport szeretete pozitív a diákok körében, $75,3 \%-a(n=1158)$ szeretnek sportolni.

1. táblázat: A válaszadók sportolási szeretete és gyakorisága nemenkénti megoszlásban (Forrás: a Szerző)

\begin{tabular}{|c|c|c|c|}
\hline \multirow{2}{*}{ Szeretsz-e sportolni? } & \multicolumn{2}{|c|}{ Nemed } & \multirow[t]{2}{*}{ Összesen } \\
\hline & Fiú & Lány & \\
\hline Igen & 495 & 377 & 872 \\
\hline
\end{tabular}




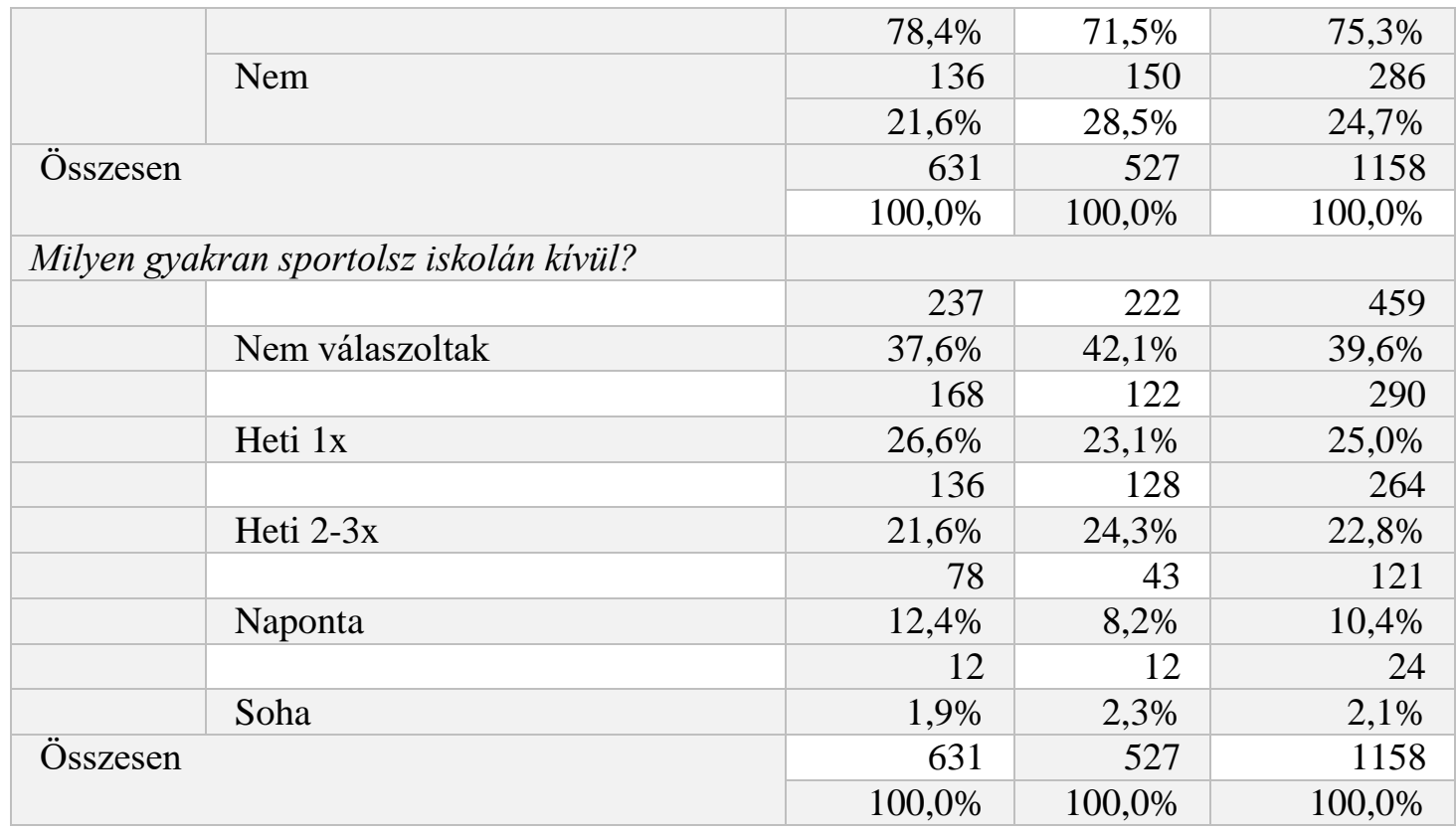

A megkérdezett fiú tanulók nagyobb arányban szeretik a sportolást $(78,4 \%, n=495)$, mint a lányok $(71,5 \%, n=377)$. A nemek körében a fiúk között szignifikánsan többen nyilatkozták azt, hogy szeretik a sportot $(p<0.05)$ (1. táblázat).

A diákok sportolási gyakoriságának eloszlását az 1. táblázatban azt mutatja, hogy a tanulók 25.\%-a hetente egyszer, 22,8\%-a hetente kétszer-háromszor, 10,4\% naponta sportol és 2,1\%-a pedig soha nem sportol. A nemek tekintetében nem mutatható ki szignifikáns különbség a sportolási gyakoriságban.

A sportolási igények felmérésénél is hasonló eredményeket tapasztalható a nemek tekintetében, de mutat, szignifikáns eltérést nem mutatkozik a vizsgált nemek tekintetében, a fiúk $77,2 \%$-uk ( $n=487)$ igényli, hogy többet sportoljon, míg a lányoknál $72,9 \%$-uk $(n=384)$. Az eredményeket a 4 . ábra szemlélteti.

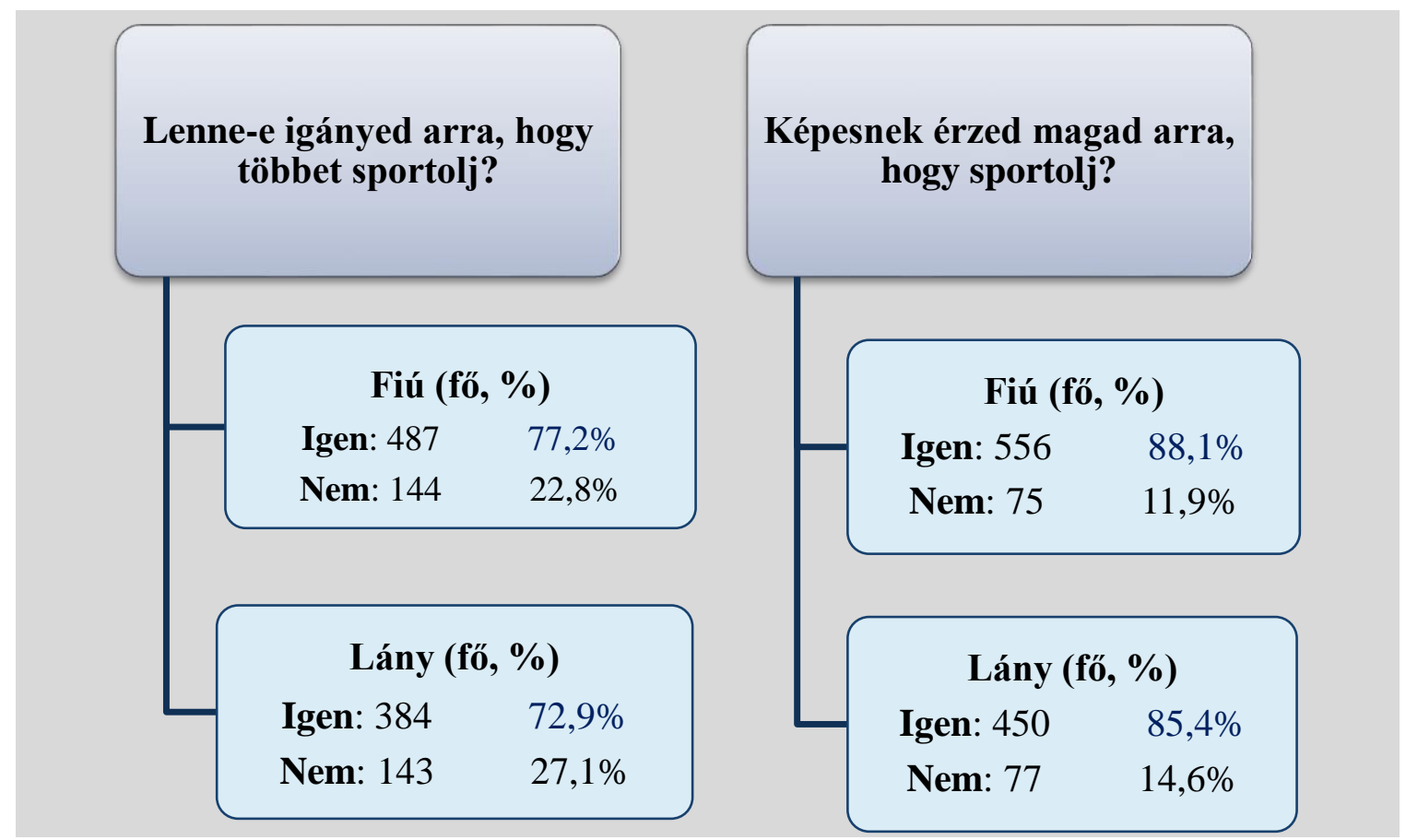

4. ábra: A felmért diákok sport szeretet iránti érdeklődése 
A fiúk $88,1 \%$-a (556 fö) nyilatkozta, hogy képesnek érzi magát a sportolásra, míg a lányok csupán 85,4\%-a (450 fö) szereti a testmozgást, amely szintén nem tapasztalható szignifikáns különbséget a mintába.

A tanulók többsége 56,4\%-a (653 fö) fontosnak tartja a fizikai aktivitást, 32,6\%-a semleges választ adott, (378 fö) és 11\%-a (127 fö), pedig nemmel válaszolt (5. ábra).

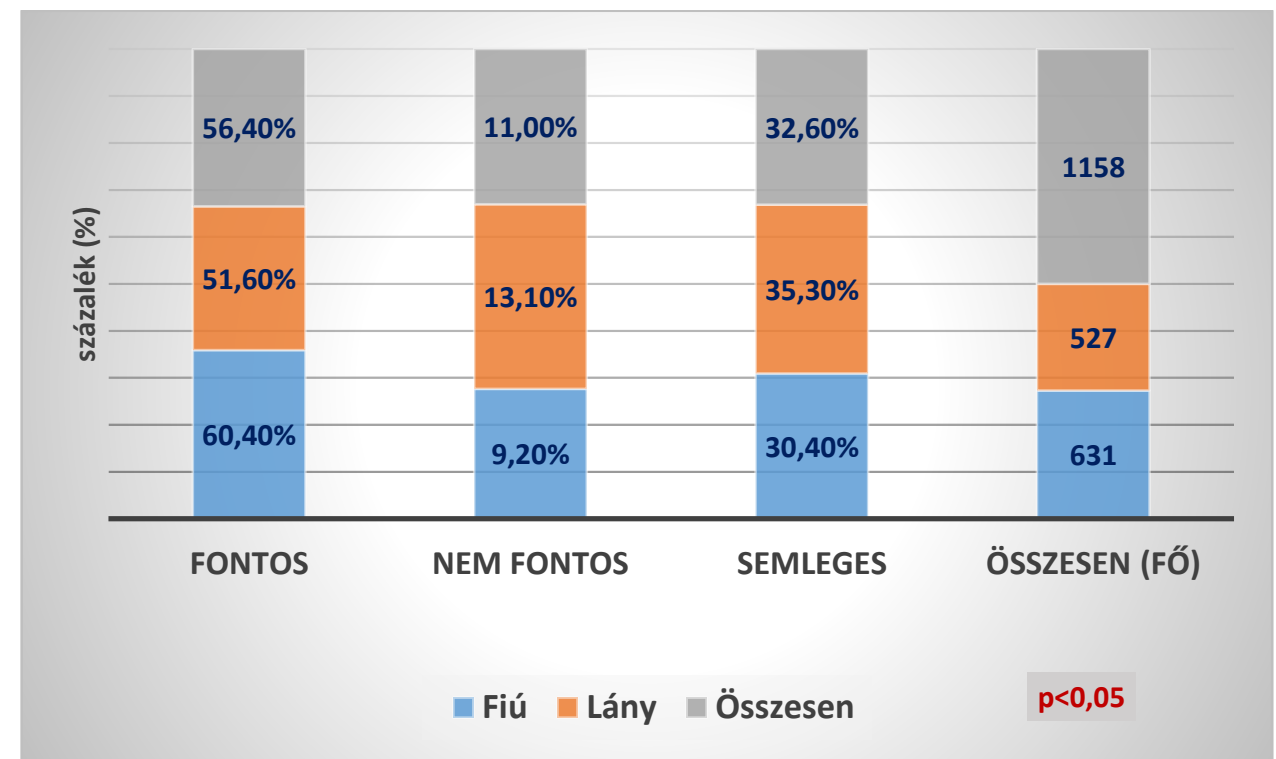

5. ábra: A felmért tanulók véleményei a sport fontosságáról

A kutatásban kiderült, hogy a fiúknál $(60,4 \%)$ fontosabb a sportolás, mint a lányoknál $(51,6 \%)$. Az 5. ábra szemlélteti az eredményeket.

\section{5. Összegzés}

A kutatás megállapította, hogy a fogyatékossággal élő tanulók nagyrésze $(75,3 \%)$ szeret sportolni, mely pozitív viszonyulás a sporthoz jó alapot kínál arra, hogy bevonjuk a tanulókat a szabadidős sportba, mellyel az egészségi állapotukat támogathatjuk és a testi képességek fejlesztésén túl a személysiségfejlődésüket is elősegítsük, és olyan képességeket fejlesszünk a sport által, mint a kitartás, küzdeni akarás, csapatszellem, mások segítése. A sport egyben szórakozást, örömet, közös programot is jelent, mely a szórakoztató funkcióján keresztül élményt ad a gyerekeknek és további motivációt a tevékenység végzéséhez.

Amennyiben a nemek sporthoz való viszonyulását elemeztük, úgy azt tapasztalhattuk, hogy a fiúk $(78,4 \%)$ és lányok $(71,5 \%)$ sportszeretete eltért (chi2=7,37, $p=0,007)$, azaz a fiúk között szignifikánsan többen nyilatkozták azt, hogy szeretik a sportot.

A sportolás gyakoriságát tekintve elmondható, hogy a fogyatékossággal élő gyerekek között $27,1 \%$ a nem sportoló vagy nem rendszeresen sportolók aránya. A heti egyszer alkalomnál kevesebbszer sportolók (25\%) és a soha nem sportolók $(2,1 \%)$ azok, akiknél a sportolás szervezetre gyakorolt pozitív hatása nem érvényesül, azaz nem jelent egészségügyi előnyt, mivel a kéthetente vagy havonta egy alkalom az a nem sportoló kategóriát jelenti. Örvendetes viszont az a tény, hogy a válaszadók közel háromnegyede sportol,mivel ezek a gyerekek iskolába járnak, így általában az iskola biztosítja a lehetőséget. Azonban a felnőtt fogyatékkalélők eseében már igen erőteljesen lecsökken a szabadidősportot üzők aránya [25].

A sportolási gyakoriság tekintetében is a fiúk bozonyultak aktívnak, ám ez csak tendenciájában igaz, hiszen a chi2 próba nem mutatott szignifikáns különbséget. A fiúk $77,2 \%-a$ lányok $72,9 \%$-a mondta, hogy lenne igénye arra, hogy többet sportoljon. A fiúk $88,1 \%$-a a lányok $85,4 \%$-a képesnek is érzi magát a sportolásra, tekintettel arra, hogy a válaszadók többsége tanulásban akadályozott tanuló volt. 
A fiú tanulók 60,4\%-a míg a lányok 51,6\%-a véli fontosnak a sportot (chi2=9,98, $p=0,007$ ).

Megállapíthatjuk azokat az eredményeket, melyek az épek körében végzett felmérésekben is hasonlóan alakulnak, azaz a fiúk sportaktivitása, sporthoz való pozitív viszonyulása és az értékelése magasabb a lányokhoz képest.

A kutatás megerősíti azt, hogy a fogyatékossággal élő diákok szeretik a sportot, igénylik és képesnek is tartják magukat az erőfeszítésre. Örvendetes, hogy ebben a populációban alacsony a nem sportolók aránya, ám ezt tovább lehetne csökkenteni, tekintettel arra, hogy igen nagy szükségük van a mozgásra, ami az egészségi állapotuk javításán túl segítheti őket a képességfejlesztésben, szocializációban, társadalmi beilleszkedésben egyaránt.

\section{Köszönetnyilvánítás}

A publikáció elkészítését „Az Innovációs és Technológiai Minisztérium ÚNKP-20-3-II-DE-315 kódszámú Új Nemzeti Kiválóság Programjának a Nemzeti Kutatási, Fejlesztési és Innovációs Alapból finanszírozott szakmai támogatásával készült."

\section{Irodalomjegyzék}

[1] Gabnai, Z; Müller, A. ; Bács, Z. ; Bácsné, Bába É.(2019): A fizikai inaktivitás nemzetgazdasági terhei. Egészségfejlesztés 60:1 pp. 20-30. 11 p. (2019).

[2] Fehér, A.; Bácsné, B. É.; Müller, A.; Szakály, Z (2019): Fizikai aktivitás motivációival kapcsolatos modellek rendszerezése I. - Szakirodalmi áttekintés. In: Fehér, András; Szakály, Zoltán (szerk.) Egészségpiaci kutatások.Debrecen, Magyarország : Debreceni Egyetem Gazdaságtudományi Kar, (2019) pp. 152-163. , 12 p.

[3] Ács, P., Stocker, M., Kovács, A., Hoffbauer, M., Szabó, P., \& Paár, D. (2020): A magyarországi fizikai inaktivitási terhek alakulásának összehasonlító elemzése, 2009-2017. Közgazdasági Szemle, 67(7-8), 809830.

[4] Molnár, E. (2019a) Kutyával asszisztált óvodai foglalkozások [Dog-assisted kindergarten activities]. Gradus 63 pp. 27-34.

[5] Molnár, E. (2019b): Elektronikus médiahasználat óvodáskorban [Electronic media use in preschool]. Gradus 6:3 pp. 16-21.

[6] Robertson, J., Emerson, E., Gregory, N., Hatton, C., Turner, S., Kessissoglou, S., \& Hallam, A. (2000). Lifestyle related risk factors for poor health in residential settings for people with intellectual disabilities. Research in developmental disabilities, 21(6), 469-486.

[7] Aitchison, B., Rushton, A., Martin, P., Soundy, A., \& Heneghan, N. R. (2020): Experiences and perceived health benefits of individuals with a disability participating in sport: A systematic review protocol. BMJ open,10(11).e038214.

[8] Czabai, V; Bíró, M ; Hajdu, Pál 82007):Az Eszterházy Károly Főiskola hallgatóinak életmódja, sportolási szokásai. Acta academiae paedagogicae agriensis nova series: sectio sport 34 pp. 29-38.10 p. (2007).

[9] Herpainé, Lakó J. ; Simon, I. Á. ; Nábrádi, Zs. ; Müller, A. (2017):Családok sportolási szokásainak szocioökonómiai hátterére. KÉPZÉS ÉS GYAKORLAT: TRAINING AND PRACTICE 15: 4 pp. 37-52. (2017).

[10] Müller, A. ; Bíró, M.; Boda, E. ; Herpainé, Lakó J. (2017): Az óvodások testtömegének és sportolási szokásainak összefüggései egy egri kutatás tükrében. Acta Academiae Paedagogicae Agriensis Nova Series: Sectio Sport 44 pp. 191-203.13 p. (2017).

[11] Anetta, Müller; Elena, Bendíková ; Judit, Herpainé Lakó ; Éva, Bácsné Bába ; Wioletta, Łubkowska ; Bożena, Mroczek: (2019): Survey of regular physical activity and socioeconomic status in Hungarian preschool children Family Medicine And Primary Care Review 21:3 pp. 237-242. , 6 p. (2019).

[12] Müller, A. (2018): Obesity and overweight in Hungary, focussing on among high school students. In: Elena,Bendíková (szerk.) Physical Activity, Health and Prevention III. : International Scientific Conference: Conference Textbook. Zilina, Szlovákia : IPV Institute of Education, IPV Inštitút priemyselnej výchovy, (2018) pp. 6-16.11 p.

[13] Balatoni, I.;Szépné Varga, H. ; Müller, A. É. ; Kovács, S.; Kosztin, N. ; Csernoch, L. (2019): Sporting habits of university students in Hungary.Baltic Journal Of Health And Physical Activity 1: Suppl. 2 pp. 27-37. , 11 p. (2019).

[14] Lenténé, Puskás A.; Biró, M.; Dobay, B. ; Pucsok, J. M. (2018): A szabadidő sportolás kínálati elemeinek, és szolgáltatásainak vizsgálata Magyarország Észak-alföldi régiójának szállodáiban. Selye E-Studies 9:1 pp. 13 21. , 9 p. (2018).

[15] Müller, A.; Bácsné, Bába É. (2018): Az egészséges életmód és a sport kapcsolata. Létavértes, Magyarország: Létavértes SC '97 Egyesület (2018), 96 p.ISBN: 9786150031897.

[16] Bíró, M. ; Hidvégi, P.; Tatár, A. ; Pucsok, M., J. ; Lenténé Puskás A. (2018):Possibilities for improving the quality of life in Hungary in the northern great plain region. In: Jaromír, Šimonek; Beáta, Dobay (szerk.) Sport science in motion : proceedings from the scientific conference. Športová veda v pohybe: recenzovaný zborník 
vedeckých a odborných prác z konferencie. Mozgásban a sporttudomány: válogatott tanulmányok a konferenciáról. Komárno, Szlovákia : Univerzita J. Selyeho, (2018) pp. 227-235.,9 p.

[17] Bácsné, Bába É. ; Balogh, R. ; Bács, Z. ; Fenyvesi, V. ; Dajnoki, K. (2018): Sportszolgáltatások keresleti, kínálati oldalának elemzési lehetőségei Studia Mundi - Economica $5: 3$ pp. 19-33.

[18] Bácsné, Bába É. ; Balogh, R. ; Bács, B. A. ; Molnár, A. ; Fenyves, V. ; Müller, A. (2019): A passzív sportfogyasztás motivációinak vizsgálata nemek tükrében. ECONOMICA (SZOLNOK) 10:1 pp. 30-35. , 6 p. (2019).

[19] Balogh, R.; Molnár, A.; Müller, A.; Szabados, Gy. N.; Bácsné, Bába É. (2019): A passzív sportfogyasztás vizsgálatának tapasztalataiból Acta Carolus Robertus 9:1 pp. 35-48.

[20] Sherrill, C., \& Williams, T. (1996). Disability and sport: psychosocial perspectives on inclusion, integration, and participation. Sport Science Review, 5(1), 42-64.

[21] Kovács, Klára (2016) Sport és inklúzió. In: Inkluzív nevelés - inkluzív társadalom. Debreceni Egyetemi Kiadó,Debrecen, pp. 294-316. ISBN 978-963-318-615-2.

[22] Cassese, F. P., \& Raiola, G. (2017). The importance of sport in disability management. Sport Science, 10(Suppl. 1), 7-11.

[23] Hidvégi P., Honfi L. (2008): Fogyatékos személyek rekreációja. Acta Academiae Paedagogicae Agriensis Nova Series: Sectio Sport 35: pp. 21-36.

[24] Coyle, C., Kinney, W. B., Riley, B., \& Shank, J. W. (Eds.). (1991): Benefits of therapeutic recreation: A consensus view. Philadelphia: Temple University.

[25] Sáringerné Sz. Zs (2014): Fogyatékossággal élők sportolási lehetőségei. In: Gál Andrea, Dóczi Tamás, Sáringerné Szilárd Zsuzsa. Társadalmi befogadás a sportban és a sport által.

[26] Smith, B., \& Sparkes, A. (2012). Disability, sport and physical activity. A critical review. In N. Watson, A. Roulstone,\& C. Thomas (Eds.), Routledge handbook of disability studies, 336-347.

[27] Yvonne, C. (1990). Fogyatékosok integrációja-nemzetközi és hazai áttekintés. Gyógypedagógiai Szemle, 4, 271-279.

[28] Könczei Gy. (1990): A rehabilitáció rehabilitációjáért! (Fogyatékos emberek a munkaerõpiacon). Szociálpolitikai Értesítö, 3.

[29] Osváth P. (2004): A fogyatékosság ügyének megjelenése a sporttudományban. Magyar Sporttudományi Szemle, 4, 44-46.

[30] Molnár, Edina (2012a): Az Osztojkán Béla Roma Szakkollégium a Szolnoki Főiskolán. Economica (Szolnok) 5 : Különszám pp. 24-28.

[31] Tatár, A.,Lenténé, P.A.,Biró, M., Pucsok, J. M., Hidvégi, P. (2018): Észak-alföldi régió szolgáltatóinak hozzáférés biztosítása a speciális igénnyel élők számára. 150-157.p. In: Válogatott tanulmányok a sporttudományok köréböl. 1. sz. 186.p. Debreceni Egyetem Sporttudományi Koordinációs Intézet.Debrecen.

[32] Laoues-Czimbalmos, N; Bácsné Bába, É ; Mező, K ; Kőnig-Görögh, D ; Müller, A (2020): Fogyatékos tanulók szabadidős preferenciarendszerének elemzése egy kutatás tükrében. International Journal Of Engineering And Management Sciences / Müszaki És Menedzsment Tudományi Közlemények 5 : 1 pp. 102-119. , 17 p.

[33] Yazicioglu, K., Yavuz, F., Goktepe, A. S., \& Tan, A. K. (2012). Influence of adapted sports on quality of life and life satisfaction in sport participants and non-sport participants with physical disabilities. Disability and health Journal, 5(4), 249-253. DOI: 10.1016/j.dhjo.2012.05.003.

[34] Gombás, J. (2017): Budapesten élő, 18-65 év közötti látássérült személyek szabadidő-sportolási szokásainak, és a szabadidősport látássérültek számára akadálymentes hozzáférésének vizsgálata (Doktori disszertáció, Testnevelési Egyetem).

[35] Aitchison, C. (2003): From leisure and disability to disability leisure: Developing data, definitions and discourses.Disability \& Society, 18(7), 955-969.

[36] Hidvégi, P. ; Bíró, M.; Lenténé, Puskás A. ; Pucsok, J. M. ; Tatár, A.(2018): Fogyatékkal élők turizmusának lehetőségei az Észak-alföldi régióban.In: Balogh, László (szerk.) Fókuszban az egészség.Debrecen, Magyarország :Debreceni Egyetem Sporttudományi Koordinációs Intézet, (2018) pp. 158-164. , 7 p.

[37] Földesi Szabó Gy. (2010): Social Exclusion/Inclusion in the Context of Hungarian Sport. Physical Culture and Sport. Studies and Research 50: 44-59.

[38] Molnár, E.; Lukács, Á. (2012b): Esélyegyenlőség a közszférában egy államilag támogatott felsőoktatási intézmény példáján keresztül. Szolnoki Tudományos Közlemények 16 pp. 496-512.

[39] Laoues-Czimbalmos, N. ; Müller, A.; Bácsné, Bába É. (2019a): Fogyatékossággal Élőgyerekek SportFogyasztási Szokásainak Vizsgálata Az Akadálymentesített Kínálati Elemek Tükrében.Economica (Szolnok) 10:1. pp.21-29.9 p.

[40] Tatár, A. ; Lenténé, Puskás A.; Biró, M.; Pucsok, M. J.; Hidvégi, P (2019): .Accessible tourism services in the North Great Plain region.Különleges Bánásmód 5:1 pp.77-81.Paper:DOI 10.18458/KB.2019.1.77,5p.

[41] Fitzgerald, H. (2018): "Sport is not for all: The transformative (im) possibilities of sport for young disabled people." Sport and physical activity across the lifespan. Palgrave Macmillan, London, 2018. 175-191.

[42] Osváth P.; Ramocsa G. (2006): A Sport Hatása a Vakok Életminőségére Magyarországon. Kalokagathia, $1-2 . s z$.

[43] Laoues-, Czimbalmos N.; Dobay, B.; Müller, A. (2019b): Examination Of The Leisure Time-Related Consumption Habits Of Young People With Disabilities With Special Emphasis On Sports. Selye E-Studies 10:2 pp. 34-45, 12 p.

[44] Borkovits, M. (2019): Vidéki fogyatékkal élő tanulók szabadidős sportolási szokásainak vizsgálata.In: Gősi,Zsuzsanna; Boros, Szilvia**; Patakiné, Bősze Júlia** (szerk.) SOKSZÍNŰ REKREÁCIÓ : Tanulmányok a 
rekreáció témaköréböl.Budapest, Magyarország : Eötvös Loránd Tudományegyetem Pedagógiai és Pszichológiai Kar, (2019) pp. 40-49. , 10 p.

[45] Balázs-Földi, E., \& Villás, M. (2020): Attitudes Towards The Sport Of Persons With Disabilities, le: Is The Sport Important In The Lives Of People With Disabilities?. Különleges Bánásmód-Interdiszciplináris folyóirat, 6(1), 1934.

[46] Kovács K. (2000): Látássérült gyermekek az óvodában és az iskolában. In: Dr. Illyés Sándor (szerk.): Gyógypedagógiai alapismeretek. ELTE BGGYFK. 461-504.

[47] Kudlacek, M. és Barrett, U. (2012): Adapted physical activity as a profession in Europe. European Journal of Adapted Physical Activity, 4. 2. sz.

[48] Gombás Judit (2011): Fogyatékosok sportja helyett adaptált sport - avagy a paradigmaváltás jótékony hatása. Magyar Sporttudományi Szemle, 12. 4. sz. 27-31.

[49] Hegyiné Honyek K. (2006): Inkluzív nevelés: Ajánlások látássérült gyermekek, tanulók, kompetencia alapú fejlesztéséhez. Óvodai nevelés - SuliNova Kht

[50] Weisz I. (2003): Látássérült személyek speciális sportja. In: Benczúr Miklósné (szerk.): Adaptált tesnevelés és sport. II. kötet. Fogyatékos személyek sportjának kiegészítő ismeretei. Fogyatékosok Nemzeti Sportszövetsége, Budapest. 183-187. 